\title{
Comparison of physique and physical fitness factors by Vitamin D Receptor Fok I polymorphism in athletic gifted children
}

\author{
Yu-Rim Kim ${ }^{1}$, Sang-Hyun Lee ${ }^{1}$, Su-Jin Kim ${ }^{1}$, Jung-Ran Song ${ }^{1}$, Hyo-Bum Kwak ${ }^{1}$, \\ Ju-Hee Kang ${ }^{2}$, \& Dong-ho Park ${ }^{1 *}$ \\ ${ }^{1}$ Department of Kinesiology, Inha University, ${ }^{2}$ Department of Pharmacology and Medicinal Toxicology Research Center, \\ College of Medicine, Inha University
}

\begin{abstract}
[Purpose] The purpose of this study is to examine the differences in physique and physical fitness factors affecting exercise performance according to the vitamin D receptor (VDR) FokI gene polymorphism in athletic gifted children. [Methods] FokI VDR polymorphisms were genotyped in 82 boys $(9.1 \pm 0.9$ years) and 55 girls ( $9.3 \pm 0.9$ years). Basic physical fitness (basketball throw, half-squat jump, standing long jump, $15 \mathrm{~m}$ pacer, $50 \mathrm{~m}$ run, handgrip strength, side-step, trunk forward flexion, sit-up) and physique were measured and analyzed using one-way ANOVA with bonferroni's correction. [Results] No association was found between the VDR FokI genotypes and all the physical fitness variables as well as physique variables in boys and girl. However, Hardy-Weinberg equilibrium results for VDR polymorphism distribution showed significant differences $\left(x^{2}=6.516, d f=2, p=.038\right)$. [Conclusion] Although there was no significant difference in the fitness variables according to the VDR Fok1 genotype, it was difficult to exclude the potential for predicting fitness in that the H-W equilibrium test showed a significant difference. Therefore, in order to confirm the true potential of the VDR Fok1 gene to predict physical fitness, it is considered that additional studies on general children should be conducted.
\end{abstract}

Key words: VDR Fok1 polymorphism, children, physical fitness, physique

\section{서 론}

경기력을 결정짓는 요인은 항목마다 다르게 요구되지 만 일반적으로 운동수행력은 근력, 근지구력, 순발력, 민 첩성 및 최대산소섭취량 $\left(\mathrm{VO}_{2} \max \right)$ 등에 의해 결정된다. 이러한 요인들은 개인이 타고난 체격, 체력 및 심리적 요 인들을 포함한 유전적 요인과 트레이닝, 영양 등과 같은 매우 다양한 환경적 요인과의 상호작용으로 나타나는 유

논문 투고일 : 2020. 06. 30 .

논문 수정일 : 2020. 07. 17.

게재 확정일 : 2020. 08. 05.

* 교신저자 : 박동호(dparkosu@inha.ac.kr).

* 이 연구는 2019년도 인하대학교 교내연구비로 수행되었음.
전적 표현형이라 한다(Park et al., 2009). 이와 같은 운 동수행력과 관련하여 엘리트선수의 운동수행력의 약 $50 \%$ 가 유전적 요인에 의해 영향을 받으며(Bouchard et al., 1998), De Moor et al.(2007)의 대규모 쌍둥이 Genome-wide linkage scan 연구에 의하면 엘리트 선수 의 강인한 체력에 대한 유전율은 약 $66 \%$ 를 차지한다고 보고되었다. 더욱이 동일한 훈련자극이 주어졌을 때 그에 적응하는 개인의 능력 차가 존재하며, 이것 역시도 개인 의 유전적 소인의 차이에서 비롯된다고 보고되었다 (Bouchard et al., 2000; Lortie et al., 1984; Thomis et al., 1998). 이렇게 개인의 훈련 적응력 또는 향상도의 차이는 유전적 소인의 차이로 인해 나타나며, 이러한 이 유로 스포츠과학 분야에서도 운동수행력과 관련된 유전 
자들에 관한 연구가 활발하게 진행되고 있다.

현재까지 밝혀진 인간의 유전자 수는 20,500 개로, case-control 연구와 연관성 연구(association study)를 통해 거론된 심폐지구력과 관련된 후보 유전자는 약 33 개(Bray et al., 2009) 그리고 근력과 무산소성 능력과 관련해서는 약 23 개의 유전자가 관련이 있는 것으로 제 안되고 있다(Bray et al., 2009; Wolfarth et al., 2005; Rankinen et al., 2004; Rankinen et al., 2002; Rankinen et al., 2001). 대표적인 운동수행력 관련 유전자로 심폐 지구력과 근력에 영향을 미치는 angiotensin-converting enzyme (ACE) 유전자가 가장 폭 넓게 연구되고 있으며 또한 중추피로 관련 세로토닌 운반체(5-HTT) 유전자, 파워지구력 관련 $\alpha$-aninin-3(ACTN3) 유전자, 근력 관 련 Vitamin D receptor(VDR) 유전자 등이 있다. 이 중 Vitamain D receptor(VDR) 유전자는 Vitamain D-내 분비계를 통해 골 항상성을 조절하기 때문에 골의 상태에 영향을 미치는 유력한 후보 유전자로 알려져 있다 (Haussler et al., 1998).

Vitamin $\mathrm{D}$ 는 골의 정상적 기질화, 장에서의 칼슘 흡수, 칼슘 및 인산염의 항상성을 조절하며, 부갑상선호르몬 $(\mathrm{PTH})$ 의 분비조절에 관여하여 골대사에 중요한 역할을 수 행하는 호르몬으로 이러한 Vitamin $\mathrm{D}$ 의 작용은 수용체인 Vitamin D receptor (VDR)를 통해 이루어진다(Morrison et al., 1994). Vitamin D receptor 유전자는 12 번 염색체 의 q13 q14에 위치하며, 9개의 엑손으로 구성되어있다. $\mathrm{VDR}$ 유전자에는 다형성이 존재하는데 엑손 8 과 9 사이의 인트론에 존재하는 Bsm I, Apa I, 그리고 Taq I 유전자 다형성을 포함하여 엑손 2에 존재하는 Fok I 제한 장다형 성 등의 다양한 대립형질 변이를 지니고 있다.

Vitamin D receptor (VDR) 유전자의 일반적인 대립유 전자 다형성은 건강한 Australian 쌍둥이들의 연구에서 모든 골밀도 차이의 $75 \%$ 이상을 설명할 수 있다고 보고되 었다(Morrison et al., 1994). Nakamura et al. (2002) 와 Tajima et al. (2000)의 연구에서는 일반 성인과 선수 를 대상으로 수행한 연구에서, VDR 유전자 다형성에 따라 충격부하에 대한 골밀도(bone mineral density; $\mathrm{BMD}$ )에 서 유의한 차이 $(\mathrm{FF}>\mathrm{Ff})$ 가 있음을 보고하였다. 또한 다른 선행 연구(Katsumata et al., 2002; Ames et al., 1999) 에서도, 골밀도와 VDR Fok I 유전자의 상관관계에 대한
연구에서 $\mathrm{FF}$ 형의 골밀도는 ff형보다 $8.2 \%$ 높았고, $\mathrm{Ff}$ 형에 비하여서는 $4.8 \%$ 높았다고 보고된 바 있다.

한편, 근력과 관련하여 여성을 대상으로 $\mathrm{VDR}$ 유전자 와의 상관성을 분석한 Grundberg et al. (2004)와 Geusens et al. (1997)의 연구에서는 VDR 유전자가 근 력과 상관성이 있음을 보고하였고, 국내의 Park et al. (2017)의 연구에서도 여성의 악력에서 VDR 유전자 중 $\mathrm{FF}$ 형이 $\mathrm{Ff}$ 형보다 유의하게 높았으며, 국가대표 선수들 중 투기종목과 중거리 종목에서 ff형의 분포가 유의하게 낮았던 결과를 바탕으로 VDR 유전자를 근력을 반영하는 유용한 후보 유전자로 판단하였다(Song et al., 2006). 이러한 결과들은 운동수행력이나 운동의 효과가 VDR 유 전자 다형성에 따라 차이가 나타날 수 있음을 시사하는 것이다. 그러나 이들 연구들의 대부분이 성인을 대상으로 이루어 졌고, 각 유전자가 가진 기능적 특성에 따라 발현 시기 또한 다를 수 있다. 일반적으로 유전자가 지닌 기능 적 특성의 발현은 유전적 소인과 환경적 소인의 상호작용 을 통해 나타난다. 따라서 특정 유전자의 기능적 특성이 트레이닝 또는 영양과 같은 환경적 요인에 의해 극대화될 수 있음을 의미하기도 하지만 유전자가 지닌 기능적 특성 의 정도 또는 영향력과도 관련이 있다. 성장 분화 인자-8 (growth differentiation factor-8: GDF-8)이라고도 하 는 myostatin(MSTN)은 TGF- $\beta$ 슈퍼 패밀리의 일원으 로, 골격근 성장의 억제 조절장치로 작용(Song et al., 2006) 하지만 MSTN 돌연변이를 지닌 사람이나 다양한 동물의 경우 환경적 영향이 적은 초기에서부터 유전자가 지닌 고유의 기능적 특성이 나타나기도 한다. 즉, 유전자 의 기능적 특성이 매우 강하다면, 그 발현시기 역시도 빠 를 수 있으며 또한 환경적 영향이 크지 않더라도 나타날 수 있을 것이다. 따라서 여러 환경적 요인들의 영향을 비 교적 적게 받은 아동을 대상으로 유전자 다형성과 체력 간의 관련성을 살펴보는 것은 매우 의미가 있다(Park et al., 2009). 국내에서는 주로 운동선수의 골밀도와 관련 하여 $\mathrm{VDR}$ 유전자 다형성 간의 상관관계에 대한 연구가 보고되고 있으나(Lee et al., 2004; Park et al., 2005; Kim et al., 2008) 체력 또는 운동수행력과의 관련성을 살펴본 연구는 매우 부족한 실정이다. 또한 대부분 성인 혹은 엘리트선수를 대상으로 이루어졌기에 아동을 대상 으로 한 연구가 필요한 실정이다. 
따라서 본 연구에서는 운동의 참여 및 연령에 의한 환 경적 영향을 비교적 적게 받을 것으로 예상되는 아동을 대상으로 Vitamin D receptor (VDR) Fok I 유전자 다 형성에 따라 운동수행력에 영향을 미치는 체격·체력요인 에 어떠한 차이가 있는지 알아보고자 한다.

\section{연구 방법}

\section{연구대상}

본 연구의 대상은 I대학교의 체육영재센터의 발굴 대상 자로서, 일반 초등학교 $2-5$ 학년 남녀학생 160 명을 선정하 였다. 대상자들에게 개인의 병력, 운동 적합성 여부 및 심 혈관 질환 유무에 대한 설문조사를 실시하여 이상이 없다 고 판단되는 아동들로 구성하였다. 또한 본 연구의 목적과 실험과정에 대하여 학부모에게 설명한 후 아동의 실험 참 여 및 유전자검사에 대한 동의를 얻어 실험을 실시하였다. 이 중 체력측정에 참여하지 못하거나 채혈을 하지 않은 12 명을 제외한 148 명에 대하여 유전자 분석을 실시하였다.

Table 1. Characteristics of physique and physical fitness in boys and girls

$($ Mean $\pm S D)$

\begin{tabular}{lcccc}
\hline \hline \multicolumn{1}{c}{ Variables } & $\begin{array}{c}\text { Boys } \\
\text { Physique }\end{array}$ & $\begin{array}{c}\text { Girls } \\
(\mathrm{n}=82)\end{array}$ & $\mathrm{t}$ & $\mathrm{p}$ \\
\hline Age (yrs) & $9.1 \pm 0.9$ & $9.3 \pm 0.9$ & -1.027 & .307 \\
Bone Age (yrs) & $9.2 \pm 1.4$ & $9.7 \pm 1.4$ & 1.938 & .055 \\
Height (cm) & $134.0 \pm 7.1$ & $133.4 \pm 8.1$ & 0.429 & .668 \\
Sitting height (cm) & $73.0 \pm 3.3$ & $71.8 \pm 4.1$ & 1.765 & .080 \\
Weight (kg) & $31.2 \pm 5.3$ & $30.0 \pm 5.5$ & 1.212 & .228 \\
Chest circumference (cm) & $65.4 \pm 4.9$ & $63.4 \pm 5.2$ & 2.225 & .028 \\
\%fat (\%) & $10.6 \pm 6.6$ & $18.6 \pm 6.7$ & -6.71 & .000 \\
\hline \multicolumn{1}{c}{ Physical fitness } & & & & \\
Basketball throw (cm) & $324.5 \pm 57.7$ & $279.5 \pm 55.3$ & 4.411 & .000 \\
Sit-up (rep) & $40.9 \pm 7.2$ & $42.4 \pm 11.3$ & -0.003 & .354 \\
Half squat jump (rep) & $58.5 \pm 9.7$ & $56.0 \pm 10.3$ & 1.368 & .174 \\
Standing long jump (cm) & $158.2 \pm 16.9$ & $140.6 \pm 16.4$ & 5.89 & .000 \\
15m pacer (min) & $61.6 \pm 18.4$ & $53.1 \pm 16.5$ & 2.672 & .009 \\
50m running (sec) & $9.7 \pm 0.7$ & $10.5 \pm 0.8$ & -5.257 & .000 \\
Side-step (rep) & $33.4 \pm 3.8$ & $30.0 \pm 4.5$ & 4.602 & .000 \\
Trunk forward flexion (cm) & $10.3 \pm 5.5$ & $13.8 \pm 4.8$ & -3.678 & .000 \\
Handgrip strength (kg) & $13.6 \pm 3.8$ & $11.7 \pm 3.5$ & 2.991 & .003 \\
\hline \hline
\end{tabular}

대상자들은 $\mathrm{VDR}$ 유전자 다형성에 따라 세 집단(FF집 단, Ff집단, ff집단)으로 구분하였고 유전자 분석 결과가 불분명한 11 명을 제외한 137 명을 분석대상으로 선정하 였다. 대상자 특성은 〈Table 1)과 같다.

\section{연구절차}

\section{1) 채혈 방법 및 DNA 추출}

대상자의 상완정맥에서 약 $3 \mathrm{ml}$ 의 혈액을 숙련된 간호 사를 통해 채취하였다. DNA 추출을 위해 채취된 정맥 혈 액 샘플 중 $500 \mu \mathrm{l}$ 의 혈액을 $1.5 \mathrm{ml}$ tube에 담아 보관하였 다. Genomic DNA 추출은 추출 kit (AccuPrep $\mathrm{r}$ ) Genomic DNA Extraction Kit, Bioneer Cor.)를 이용 하였고, DNA 분리 후 DNA가 추출되었는지를 확인하기 위하여 최종 얻은 투명한 액체 (eluent)를 spectrophotometer(ebiogen, Korea)를 이용하여 A260/A280 비율에 서 $\mathrm{DNA}$ 의 농도를 확인하였다. DNA 추출의 구체적인 방 법은 다음과 같다(AccuPrep Genomic DNA Extraction

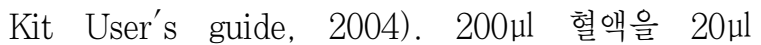
proteinase $\mathrm{K}$ 와 함께 $1.5 \mathrm{ml}$ tube에 섞은 후 다시 $200 \mu \mathrm{l}$ $\mathrm{GC}$ buffer를 첨가시켜 vortex하여 내용물이 잘 섞이도록 하였다. 섞인 혈액 혼합물을 $60^{\circ} \mathrm{C}$ 의 Thermo bath에서 10 분 동안 넣어둠으로써 온열을 시키고 다시 $100 \mu l$ Isoprophanol을 첨가시킨 후 vortex를 실시하였다. 제조 된 sample을 column tube의 upper reservoir에 부어서 옮긴 후 1 분간 $8,000 \mathrm{rpm}$ 으로 원심분리 시켜준 후, 액체 만 버리고 그대로 column tube를 collection tube (2ml) 에 옮겼다. 옮겨진 collection tube에 W1 500l buffer 를 첨가시킨 후 1 분간 $8,000 \mathrm{rpm}$ 으로 원심분리를 실시 하였다. 원심분리 후 다시 액체만 버린 후 그대로 column tube를 휴지로 닦아 넣었다.

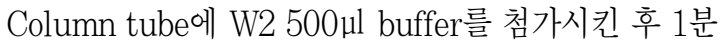
간 $8,000 \mathrm{rpm}, 1$ 분간 $12,000 \mathrm{rpm}$ 으로 원심분리를 실시 한 후 최종적으로 column tube만 제거한 후, 걸러진 투 명한 액체를 보관함으로써 최종적으로 혈액에서의 DNA 추출작업을 완료하였다. 완료된 $\mathrm{DNA}$ 는 $-20^{\circ} \mathrm{C}$ 냉동고에 서 보관하였다. 


\section{2) VDR 유전자 중합효소 연쇄반응 및 유전자} 다형성 판독

추출된 $\mathrm{DNA}$ 를 바탕으로 중합효소 연쇄반응 (polymerase chain reaction; PCR)은 $3 \mu \mathrm{l}$ 의 DNA 주형

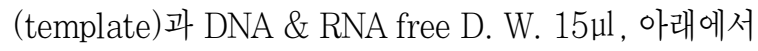
제시한 Fok I VDR (vitamin D receptor) primer를 각 $1 \mu \mathrm{l}$ 씩 혼합하여 총 $20 \mu \mathrm{l}$ 를 이용하여 PCR Thermal Cycler (ASTEC, PC-808-02)를 이용하여 PCR을 실시 하였다. PCR 생성물 $(20 \mu l)$ 중 $9.8 \mu l$ 의 product에 $10 x b u f f e r 1.2 \mu \mathrm{l}$ 를 혼합한 후 $1 \mathrm{U}$ Fok I 제한효소를 $1 \mu \mathrm{l}$ 첨가하여 $37^{\circ} \mathrm{C}$ 에서 12 시간 동안 배양하였다. 최종 생성 물을 $3 \%$ agarose gel에 30 분간 전기영동시킨 뒤 이미지 분석기(Ingenius HR, SYNGENE)를 이용하여 판독하 였다.

\section{3) 체격 및 체력 측정}

본 실험을 위하여 체육영재센터에서 지정한 체격(신 장, 좌고, 체중, 흉위, 체지방률, 골연령), 체력 (상지순발 력, 복근지구력, 하지근지구력, 하지순발력, 심폐지구력, 근력, 스피드, 민첩성, 유연성)을 측정하였다.

(1) 체격 측정

(1) 신장, 좌고 및 체중

신장계(HIE-401, KOR)와 좌고계(S1640-1, KOREA) 를 이용하여 신장과 좌고를 계측하였다. 대상자는 맨발로 신장계의 세움대에 등을 대고 직립자세를 취한 뒤, 머리 는 정면을 향하여 옆으로 기울지 않도록 하고 몸이 바르 게 된 후에 계측하였다. 좌고는 등 부분 및 둔부를 좌고계 의 척주에 접하게 하고 걸상에 허리를 곧게 펴고 앉은 뒤 계측하였다. 체중은 대상자가 체중계 $(\mathrm{DB}-60 \mathrm{H}, \mathrm{CAS}$, $\mathrm{KOREA})$ 의 저울 중심부에 오른 뒤 수치가 정지되었을 때 계측하였다.

\section{(2) 흥위}

선 자세로 두 팔을 자연스럽게 폈다가 측정자 몸 양쪽에 내리게 하고, 계측자는 줄자 $(\mathrm{KMC}-220, \mathrm{KOMERON}$, Korea)를 뒤쪽은 견갑골 직하부에, 앞쪽은 유두부 직상 부에 대고 수평위치가 되도록 하였다. 한정된 호흡을 시 켜 호기가 끝날 무렵에 측정하였다.

\section{(3) 체지방률}

체지방률은 피하지방측정기 (TKK5011a, Cambridge Scientific Industries, USA)를 이용하여 측정하였다. 남자의 경우 가슴, 복부, 대퇴부위, 여자의 경우 상완삼두 근, 상장골극, 대퇴부위의 피하지방 두께를 측정하여 Jackson-Pollock의 공식(Jackson \& Pollock, 1985)으 로 체지방률을 계산하였다. 2회 계측하여 평균값을 기록 하였다.

(4) 골연령

골연령 (bone age)은 좌측 손을 X-ray(Progen 525R, Listem, KOREA)로 촬영한 후, 손목빼와 손가락의 빼의 골화 정도를 점수화한 TW3를 이용하여 RUS(Radius, Ulna and Short bone) 수치를 정하였다(Tanner et al., 2001).

(2) 체력 측정

(1) 농구공 멀리 던지기

상지순발력 측정을 위하여 농구공멀리던지기 (Basketball throw)를 실시하였다. 대상자는 엉덩이, 등, 머리를 벽에 편하게 기대어 앉고, 바닥에 다리를 수평 으로 뻗은 상태에서 농구공(BB5316, Star, KOREA)을 가능한 멀리 수평으로 체스트 패스하게 하였다. 벽에서부 터 농구공이 첫 번째 바운드된 곳까지의 거리를 $\mathrm{cm}$ 단위 로 측정하였고 2회 실시하게 하였다.

(2) 윗몸 일으키기

복근지구력 측정을 위하여 윗몸 일으키기(sit-up)를 실시하였다. 윗몸일으키기는 계측원이 대상자의 무릎 안 쪽에 두 팔을 넣어 고정한 뒤 측정하였다. 발을 $30 \mathrm{~cm}$ 정 도 벌리고 무를을 직각으로 굽혀 세운 뒤 양 손을 가슴에 $\mathrm{X}$ 자 형태로 올려놓은 상태에서 실시하였다. 1 분 동안 실 시한 횟수를 계측하였으며 1회 실시하였다. 양 팔이 무릎 에 닿지 않거나 몸을 일으킬 때 허리와 엉덩이의 반동을 이용하면 계측에서 제외하였다.

(3) 하프스쿼트점프

하지근지구력 측정을 위하여 하프스쿼트점프(half-squat jump test)를 실시하였다. 양 옆에 기둥을 설치한 후 고 무줄을 연결하였다. 대상자는 기둥 가운데에서 측정을 실 시하였고 무릎 높이에 고무줄의 높이를 맞추었다. 팔을 
양쪽 허리에 얹은 상태에서 실시하며 무릎을 펴서 위로 점프하게 하였다. 점프 시에는 반드시 다리를 펴야하며 점프가 끝나 무릎을 굽힌 자세에서는 반드시 엉덩이 부분 이 무릎 높이의 고무줄에 닿아야 점수로 기록하였다. 1 분 동안 실시한 횟수를 계측하였다.

(4) 제자리 멀리 뛰기

하지순발력 측정을 위하여 제자리 멀리뛰기 (standing broad jump)를 실시하였다. 대상자에게 설치된 구름판 (ZM700, Star, KOREA) 위에 흰색 선을 밟지 않고 올라 선 후 최대한 멀리 점프하게 하였다. 신체의 어느 한 부분 이라도 바닥에 닿은 가장 가까운 지점에서부터 구름판 앞 까지의 직선거리를 $\mathrm{cm}$ 단위로 측정하였다. 두 번 실시하 였으며 좋은 기록을 택해 기록하였다.

\section{(5) $15 \mathrm{~m}$ PACER}

심폐지구력 측정을 위하여 왕복오래달리기 (endurance shuttle run; ESR)를 실시하였다. 대상자는 매분마다 점점 빨라지도록 정해진 속도에 맞추어 $15 \mathrm{~m}$ 거리를 가능 한 오래 왕복하여 달린다. 점증속도에 따라 울리는 신호 음이 녹음된 $\mathrm{CD}$ 를 재생하였다. $20 \mathrm{~m}$ 거리의 양 끝 지점 에 라인을 긋고 $\mathrm{CD}$ 에서 나오는 신호음이 울리기 전에 $20 \mathrm{~m}$ 거리를 가로질러 달리게 하였다. 신호가 울리기 전 에 반대편 라인에 도달한 대상자는 신호가 울릴 때까지 기다려야 하며 신호가 울리면 반대쪽 라인 끝을 향해 달 려야 한다. 신호음이 울리기 전에 라인에 도달하지 못했 을 경우 최초 1 회는 신호가 울릴 때 방향을 바꾸어 달릴 수 있다. 그러나 두 번째로 신호음이 울리기 전에 라인에 도달하지 못한 경우에는 탈락이 되어 검사를 종료하였다. 검사가 종료된 시점까지의 총 실시 횟수를 계측하였다.

\section{(6) 악력}

근력 측정을 위하여 악력 (grip strength) 측정을 실시 하였다. 편안한 자세로 서서 양 다리는 약간 벌려서 직립 자세를 취하게 하였다. 대상자의 손에 맞도록 악력계 (TKK-5401, Takei, JAPAN)의 폭을 조절하였다. 대상 자는 손가락 제2관절이 직각이 되도록 악력계를 잡고 순 간적으로 힘을 주어 측정하였다. 주로 사용하는 손으로 측정을 실시하였고, 악력계를 잡은 팔이나 악력계가 몸에 닿거나 팔이 굽어지면 파울로 간주하였다.
(7) $50 \mathrm{~m}$ 달리기

스피드 측정을 위하여 $50 \mathrm{~m}$ 달리기를 실시하였다. 출 발신호원이 출발선 앞 왼쪽 약 $5 \mathrm{~m}$ 지점에 위치하여 '제자 리에' 구령을 하며 깃발을 땅에 댄 후 '차렷' 구령 후 적당 한 시기에 깃발을 들어 출발시켰다. 대상자는 스탠딩스타 트 자세로 준비했다가 신호와 동시에 출발하였다. 출발신 호 깃발이 땅에서 떨어지는 순간부터 주자의 몸통이 결승 선에 닿을 때까지의 시간을 $1 / 10$ 초 단위로 계측하였으며 1회 실시하였다.

(8) 사이드스텝 테스트

민첩성 측정을 위하여 사이드스텝테스트(side step test)를 실시하였다. 중앙에서 양쪽에 $100 \mathrm{~cm}$ 되는 위치 에 tape를 부착하였다. 대상자는 준비자세로 중앙선을 중심으로 어깨너비로 양쪽 발을 벌려서 서고 '시작'과 함 께 step하여 한쪽 발을 오른쪽(혹은 왼쪽)선을 넘어 같은 자세를 유지하도록 하였다. 다시 중앙선을 중심으로 양쪽 발을 움직이고 실시 시간이 끝날 때까지 계속하여 오른쪽 (혹은 왼쪽)선을 넘는다. 한 칸 이동할 때마다 1 회로 인 정하며 20초 동안 실시하였다.

(9) 앉아 윗몸 앞으로 굽히기

유연성 측정을 위하여 앉아 윗몸 앞으로 굽히기 (sit and reach)를 실시하였다. 대상자는 신발을 벗고 양 발 바닥이 측정기구의 수직면에 완전히 닿도록 무릎을 펴고 바르게 앉는다. 양 발 사이의 넓이는 $5 \mathrm{~cm}$ 를 넘지 않게 하 며 양 손바닥을 곧게 펴고 왼손바닥을 오른 손등위에 올 려 겹치게 하여 준비 자세를 취한다. 상체를 천천히 굽히 면서 디지털 좌전굴측정기 $(\mathrm{WN}-\mathrm{FAS}-5111$, Fas, $\mathrm{KOREA})$ 의 눈금 아래로 손을 뻗친다. 대상자가 윗몸을 앞으로 굽힐 때 무릎이 굽혀지지 않도록 대상자의 무릎을 가볍게 눌러주었다. 손가락 끝이 2 초 정도 멈춘 지점의 막대자 눈금을 읽어서 $0.1 \mathrm{~cm}$ 단위로 기록하였으며 2회 실시하여 좋은 기록을 기록하였다.

\section{자료처리방법}

자료의 통계적 검증은 PASW(SPSS) 18.0 통계 프로 그램을 이용하였다. 분석항목에 대한 평균 및 표준편차를 산출하였다. 또한 유전자 다형성을 구성하는 관찰된 유전 
자형 분포가 대립 유전자 빈도로부터 예측된 유전자형 빈 도로부터 Hardy-Weinberg 평형을 이루는지 조사하기 위하여 교차분석 $\left(\chi^{2}\right)$ 을 이용하였다. VDR Fok I 유전자 다형성별 체격 및 체력요인 등의 변인들에 대한 집단별 차이 검증은 일원변량분석(one-way ANOVA)을 사용하 였고, 변량분석 후 유의성이 있을 경우 그 차이를 알아보 기 위하여 사후분석으로 bonferroni를 이용하였다. 또한 체력 변인과 체격 변인간 상관분석을 실시한 후 상관성이 높게 나타난 체력변인에 한하여 회귀 분석을 실시하였다. 모든 통계적 유의수준 $(\alpha)$ 은 0.05 로 설정하였다.

\section{연구결과}

\section{VDR 유전자 다형성의 분포}

총 148 명 중 유전자 분석 결과가 불분명한 11 명을 제 외한 137 명의 $\mathrm{VDR}$ 유전자 다형성 분포에 대한 Hardy-Weinberg 평형에 대한 결과를 〈Table 2〉에 제시 하였다. $\mathrm{FF}$ 집단은 총 51 명으로 $37.2 \%$ 의 분포를 보였으 며 $\mathrm{Ff}$ 집단은 76 명으로 $55.5 \%$, ff집단은 10명으로 $7.3 \%$ 의 분포를 나타내었다. 또한 관측된 유전자형 분포가
Hardy-Weinberg 평형 상태를 이루는지 분석한 결과 $p=0.038$ 로 유의하게 차이가 있는 것으로 관측되었다.

Table 2. Distribution of VDR gene polymorphisms and alleles in children

\begin{tabular}{ccccccc}
\hline \hline & \multicolumn{3}{c}{ VDR frequency (\%) } & & \multicolumn{2}{c}{ Allele frequency (\%) } \\
\cline { 2 - 3 } \cline { 6 - 7 } Genotype & $\begin{array}{c}F F \\
(\%)\end{array}$ & $\begin{array}{c}\text { Ff } \\
(\%)\end{array}$ & $\begin{array}{c}\text { ff } \\
(\%)\end{array}$ & & $\begin{array}{c}F \\
(\%)\end{array}$ & $\begin{array}{c}\mathrm{f} \\
(\%)\end{array}$ \\
\hline Children & 51 & 76 & 10 & & 89 & 48 \\
$(137)$ & $(37.2)$ & $(55.5)$ & $(7.3)$ & & $(65)$ & $(35)$ \\
& 57.8 & 62.4 & 16.8 & & \\
H-W & $\begin{array}{c}57.8 \\
\end{array}$ & $(42.2)$ & $(45.5)$ & $(12.3)$ & & \\
\hline \hline
\end{tabular}

$\mathrm{H}-\mathrm{W}$ : hardy-weinberg equilibrium.

H-W $\mathrm{W}^{\mathrm{a}}$ expected: $\chi^{2}=6.516, \mathrm{df}=2, \mathrm{p}=0.038$

\section{VDR 유전자 다형성과 체격 및 체력 요인 비교}

1) 성별 및 VDR 유전자 다형성에 따른 체격 및 체 력 요인 비교

〈Table 3〉은 성별에 따른 VDR 유전자 다형성별 체격 및 체력 요인을 분석한 결과이다. 총 137 명 중 남아 82 명 (59.9\%)과 여아 55명(40.1\%)이었고, 유전자형별로는

Table 3. Comparisons of distribution of VDR gene polymorphisms in boys and girls

$($ Mean $\pm S D)$

\begin{tabular}{|c|c|c|c|c|c|c|}
\hline \multirow{3}{*}{ Group (N=137) } & \multicolumn{6}{|c|}{ VDR genotype } \\
\hline & \multicolumn{2}{|c|}{$\mathrm{FF}(\mathrm{n}=51,37.2 \%)$} & \multicolumn{2}{|c|}{$\mathrm{Ff}(\mathrm{n}=76,55.5 \%)$} & \multicolumn{2}{|c|}{$\mathrm{ff}(\mathrm{n}=10,7.3 \%)$} \\
\hline & boys $(n=28)$ & $\operatorname{girls}(n=23)$ & boys $(n=46)$ & $\operatorname{girls}(n=30)$ & boys $(\mathrm{n}=8)$ & $\operatorname{girls}(n=2)$ \\
\hline Boys, $n=82($ Girls, $n=55)(\%)$ & 54.9 & 45.1 & 60.5 & 39.5 & 80 & 20 \\
\hline Age (yrs) & $9.0 \pm 1.0$ & $9.3 \pm 0.9$ & $9.2 \pm 0.9$ & $9.3 \pm 0.9$ & $9.0 \pm 0.8$ & $8.5 \pm 0.7$ \\
\hline Bone Age (yrs) & $9.2 \pm 1.4$ & $9.6 \pm 1.5$ & $9.2 \pm 1.5$ & $9.8 \pm 1.3$ & $9.5 \pm 0.9$ & $8.4 \pm 0.9$ \\
\hline Height $(\mathrm{cm})$ & $133.3 \pm 6.7$ & $133.3 \pm 8.7$ & $134.4 \pm 7.3$ & $133.4 \pm 7.7$ & $138.1 \pm 6.6$ & $129.6 \pm 7.1$ \\
\hline Sitting height $(\mathrm{cm})$ & $72.9 \pm 3.4$ & $72.1 \pm 3.8 .0$ & $73 \pm 3.3$ & $69.5 \pm 12.4$ & $74.2 \pm 3.2$ & $70.8 \pm 2.3$ \\
\hline Weight (kg) & $30.9 \pm 5.4$ & $29.8 \pm 5.9$ & $31.4 \pm 5.3$ & $30.2 \pm 5.2$ & $33.8 \pm 5.6$ & $27.4 \pm 1.5$ \\
\hline Chest circumference $(\mathrm{cm})$ & $65.5 \pm 5.2$ & $63.5 \pm 6.2$ & $65.3 \pm 4.8$ & $63.4 \pm 4.3$ & $67.0 \pm 7.2$ & $58.8 \pm 1.8$ \\
\hline$\%$ fat (\%) & $10.0 \pm 6.5$ & $18.3 \pm 6.3$ & $11.0 \pm 6.7$ & $18.8 \pm 7.1$ & $12.9 \pm 10.7$ & $13.8 \pm 0.3$ \\
\hline Basketball throw $(\mathrm{cm})$ & $336.1 \pm 60.0$ & $271.1 \pm 56.7$ & $317.5 \pm 55.6$ & $286 \pm 54.2$ & $353.8 \pm 48.7$ & $235 \pm 49.5$ \\
\hline Sit-up (rep) & $41.3 \pm 6.5$ & $40.4 \pm 11.6$ & $40.7 \pm 7.6$ & $44.0 \pm 11.0$ & $44.4 \pm 9.5$ & $52.5 \pm 16.3$ \\
\hline Half squat jump (rep) & $60.0 \pm 9.0$ & $56.1 \pm 9.0$ & $57.6 \pm 10.1$ & $56.0 \pm 11.3$ & $56.3 \pm 11.5$ & $61.0 \pm 8.5$ \\
\hline Standing long jump (cm) & $159.6 \pm 16.6$ & $139.7 \pm 15.5$ & $157.4 \pm 17.2$ & $141.2 \pm 17.3$ & $163.0 \pm 19.6$ & $140.0 \pm 0.0$ \\
\hline $15 \mathrm{~m}$ pacer (min) & $62.2 \pm 17.6$ & $52.4 \pm 16.9$ & $61.2 \pm 19.1$ & $53.6 \pm 16.5$ & $57.5 \pm 19.4$ & $50.5 \pm 20.5$ \\
\hline $50 \mathrm{~m}$ running $(\mathrm{sec})$ & $9.6 \pm 0.5$ & $10.4 \pm 0.7$ & $9.8 \pm 0.8$ & $10.5 \pm 0.9$ & $9.9 \pm 0.7$ & $10.5 \pm 0.1$ \\
\hline Side-step (rep) & $33.4 \pm 2.8$ & $29.9 \pm 3.8$ & $33.4 \pm 4.4$ & $30.0 \pm 5.1$ & $34.1 \pm 4.9$ & $29.5 \pm 4.9$ \\
\hline Trunk forward flexion $(\mathrm{cm})$ & $11.1 \pm 4.9$ & $14.0 \pm 4.7$ & $9.8 \pm 5.8$ & $13.6 \pm 5.0$ & $9.0 \pm 3.1$ & $19.1 \pm 3.5$ \\
\hline Grip strength $(\mathrm{kg})$ & $13.1 \pm 3.6$ & $11.7 \pm 3.3$ & $13.9 \pm 3.9$ & $11.6 \pm 3.7$ & $14.8 \pm 3.9$ & $10.0 \pm 2.8$ \\
\hline
\end{tabular}


$\mathrm{FF}, \mathrm{Ff}$ 및 ff형 각각 51명 (37.2\%), 76명 (55.5\%), 10명 (7.3\%)이었다. 또한 유전자형별 남녀 분포를 살펴보면, 51 명의 $\mathrm{FF}$ 형은 남녀 아동 각각 $54.9 \%$ 와 $45.1 \%, \mathrm{Ff}$ 형 은 남녀 아동 각각 $60.5 \%$ 와 $39.5 \%$ 그리고 $\mathrm{ff}$ 형은 각각 $80 \%$ 와 $20 \%$ 로 구성되어 있다.

분석 결과 VDR 유전자 다형성별 체격 및 체력의 유의 한 차이가 나타나지 않았다. 흥미로운 것은 좌전굴을 제 외하고 여아보다 남아가 체력변인들에서 우수하였으나 남아의 분포가 상대적으로 가장 낮은 $\mathrm{FF}$ 형 집단의 남아 와 여아 모두 하프스쿼트 점프, $15 \mathrm{~m}$ 왕복달리기, $50 \mathrm{~m}$ 달리기, 좌전굴에서 가장 높거나 빠른 경향을 보였다. 남 녀를 비교한 결과에서도 FF집단의 남아가 연령, 골연령, 키, 체전굴을 제외한 모든 요인에서 높은 경향을 나타냈 다. Ff집단에서는 남아가 연령, 골연령, \%fat, 윗몸일으 키기, 체전굴을 제외한 모든 요인에서 여아보다 높은 경 향을 나타냈다. ff집단에서는 남아가 \%fat, 윗몸일으키 기, 하프스쿼트점프, 체전굴을 제외한 모든 요인에서 여 아보다 높은 경향을 나타냈다.

Table 4. Comparisons of distribution of VDR gene polymorphisms in children

$($ Mean $\pm S D)$

\begin{tabular}{cccccc}
\hline \hline & \multicolumn{5}{c}{ VDR genotype } \\
\cline { 2 - 6 } Group(N=137) & $\begin{array}{c}\mathrm{FF} \\
(\mathrm{n}=51)\end{array}$ & $\begin{array}{c}\mathrm{Ff} \\
(\mathrm{n}=76)\end{array}$ & $\begin{array}{c}\mathrm{ff} \\
(\mathrm{n}=10)\end{array}$ & $\mathrm{F}$ & $\mathrm{p}$ \\
\hline Age (yrs) & $9.1 \pm 1.0$ & $9.3 \pm 0.9$ & $8.9 \pm 0.7$ & .781 & .460 \\
Bone Age (yrs) & $9.4 \pm 1.5$ & $9.4 \pm 1.4$ & $9.3 \pm 1.0$ & .047 & .954 \\
Height (cm) & $133.3 \pm 7.6$ & $134.0 \pm 7.4$ & $136.4 \pm 7.2$ & .740 & .479 \\
Sitting height (cm) & $72.5 \pm 3.6$ & $71.7 \pm 8.3$ & $73.5 \pm 3.2$ & .500 & .607 \\
Weight (kg) & $30.4 \pm 5.6$ & $30.9 \pm 5.3$ & $32.5 \pm 5.7$ & .645 & .526 \\
Chest circumference (cm) & $64.6 \pm 5.7$ & $64.6 \pm 4.7$ & $65.4 \pm 7.2$ & .106 & .899 \\
\%fat (\%) & $13.8 \pm 7.6$ & $14.1 \pm 7.8$ & $13.1 \pm 9.5$ & .082 & .921 \\
Basketball throw (cm) & $306.8 \pm 66.5$ & $305.1 \pm 56.9$ & $330.0 \pm 68.0$ & .734 & .482 \\
Sit-up (rep) & $40.9 \pm 9.1$ & $42.0 \pm 9.2$ & $46.0 \pm 10.6$ & 1.279 & .282 \\
Half squat jump (rep) & $58.3 \pm 9.1$ & $56.9 \pm 10.5$ & $57.2 \pm 10.7$ & .267 & .766 \\
Standing long jump (cm) & $150.6 \pm 18.9$ & $151.0 \pm 18.9$ & $158.4 \pm 19.9$ & .744 & .477 \\
15m pacer (min) & $57.8 \pm 17.8$ & $58.2 \pm 18.4$ & $56.1 \pm 18.7$ & .060 & .942 \\
50m running (sec) & $10.0 \pm 0.7$ & $10.1 \pm 0.9$ & $10.0 \pm 0.7$ & .265 & .768 \\
Side-step (rep) & $31.8 \pm 3.7$ & $32.1 \pm 4.9$ & $33.2 \pm 5.0$ & .379 & .685 \\
Trunk forward flexion (cm) & $12.4 \pm 5.0$ & $11.3 \pm 5.8$ & $11.0 \pm 5.2$ & .706 & .495 \\
Grip strength (kg) & $12.5 \pm 3.5$ & $13.0 \pm 3.9$ & $13.9 \pm 4.1$ & .682 & .507 \\
\hline \hline There were no significant differences in all variables. & & &
\end{tabular}

2) VDR Fok1 유전자 다형성별 체격 및 체력 요인 비교 〈Table 4〉에서는 성별의 구분 없이 VDR 유전자 다형 성별 체격 및 체력 요인에 대한 결과를 제시하였다. 남녀 및 VDR Fok1 유전자 다형성의 분류에 따른 비교와 마찬 가지로 $\mathrm{FF}$ 형, $\mathrm{Ff}$ 형 및 $\mathrm{ff}$ 형 세 집단 간의 유의한 차이는 나타나지 않았다.

\section{3) 두 집단(FF, Ff $+f f)$ 의 VDR 유전자 다형성에 따른 체격 및 체력 요인}

〈Table 5〉은 VDR 유전자 다형성을 두 집단(FF vs. $\mathrm{Ff}+\mathrm{ff})$ 으로 구분하여 체격 및 체력 요인을 비교, 분석한 결과이다. 선행연구를 기반으로(Nakamura et al., 2002), 〈Table 5〉에 나타난 것처럼 상대적으로 적은 분 포의 ff집단 10 명을 $\mathrm{Ff}$ 집단에 포함하여 $\mathrm{Ff}+\mathrm{ff}$ 집단으로 분류한 후 분석을 실시하였다. $\mathrm{FF}$ 집단과 $\mathrm{Ff}+\mathrm{ff}$ 집단의 체 격요인 평균은 비슷한 경향을 보였으며, 마찬가지로 두 집단 간에 체격을 포함한 체력 변인들 모두 유의한 차이 가 나타나지 않았다.

Table 5. Comparison of physique and fitness factors according to two groups (FF, Ff+ff) of VDR gene polymorphism

$($ Mean $\pm \mathrm{SD})$

\begin{tabular}{cccc}
\hline \hline & \multicolumn{3}{c}{ VDR genotype } \\
\cline { 2 - 4 } Group (N= 137) & $\begin{array}{c}\mathrm{FF} \\
(\mathrm{n}=51)\end{array}$ & $\begin{array}{c}\mathrm{Ff}+\mathrm{ff} \\
(\mathrm{n}=86)\end{array}$ & $\mathrm{p}$ \\
\hline Age (yrs) & $9.1 \pm 1.0$ & $9.2 \pm 0.9$ & .650 \\
Bone Age (yrs) & $9.4 \pm 1.5$ & $9.4 \pm 1.4$ & .877 \\
Grade & $3.2 \pm 1.0$ & $3.2 \pm 0.9$ & .639 \\
Height (cm) & $133.3 \pm 7.6$ & $134.3 \pm 7.4$ & .459 \\
Sitting height (cm) & $72.5 \pm 3.6$ & $71.9 \pm 7.9$ & .575 \\
Weight (kg) & $30.4 \pm 5.6$ & $31.1 \pm 5.3$ & .460 \\
Chest circumference (cm) & $64.6 \pm 5.7$ & $64.7 \pm 5.0$ & .956 \\
\%fat (\%) & $13.8 \pm 7.6$ & $14.0 \pm 8.0$ & .880 \\
Basketball throw (cm) & $306.8 \pm 66.5$ & $308.0 \pm 58.4$ & .912 \\
Sit-up (rep) & $40.9 \pm 9.1$ & $42.4 \pm 9.4$ & .349 \\
Half squat jump (rep) & $58.3 \pm 9.1$ & $57.0 \pm 10.5$ & .467 \\
Standing long jump (cm) & $150.6 \pm 18.9$ & $151.9 \pm 19.0$ & .697 \\
15m pacer (min) & $57.8 \pm 17.8$ & $58.0 \pm 18.3$ & .963 \\
50m running (sec) & $10.0 \pm 0.7$ & $10.1 \pm 0.9$ & .477 \\
Side-step (rep) & $31.8 \pm 3.7$ & $32.2 \pm 4.9$ & .657 \\
Trunk forward flexion (cm) & $12.4 \pm 5.0$ & $11.3 \pm 5.7$ & .239 \\
Grip strength (kg) & $12.5 \pm 3.5$ & $13.1 \pm 3.9$ & .331 \\
\hline \hline
\end{tabular}




\section{3. 남여 아동의 체격 및 체력 요인에 대한 상관성 및 회귀식에 의한 수행력 예측 모형}

〈Table 6〉은 대상자들의 체격 및 체력요인 간 상관성 을 분석한 결과이다. 농구공 던지기의 경우 신장 $(\mathrm{r}=$ .705)이 가장 높은 정상관을 보였고 체중, 흥위, 연령, 골 연령 순으로 나타났다. 윗몸 일으키기의 경우 연령 $(\mathrm{r}=$ .370)이 가장 높은 정상관을 보였고 \%fat, 골연령, 신장 순으로 나타났다. 하프 스쿼트 점프의 경우 \% fat $(\mathrm{r}=$ - 497)이 가장 높은 역상관을 보였고 흉위, 체중 순으로 나타났다. 제자리 멀리뛰기의 경우 연령 $(\mathrm{r}=.526)$ 이 가 장 높은 정상관을 보였고 신장, \%fat 골연령, 체중, 흥위 순으로 나타났다. 왕복 달리기의 경우 \%fat $(\mathrm{r}=-.478)$
이 가장 높은 역상관을 보였고 연령이 그 다음으로 나타 났다. $50 \mathrm{~m}$ 달리기의 경우 연령 $(\mathrm{r}=.477)$ 이 가장 높은 정상관을 보였고 \%fat, 신장, 골연령, 체중 순으로 나타 났다. 사이드 스텝의 경우 연령 $(\mathrm{r}=.548)$ 이 가장 높은 정 상관을 보였고 \%fat, 신장, 골연령 순으로 나타났다. 악 력은 신장 $(\mathrm{r}=.642)$ 과 가장 높은 정상관을 보였고 연령, 체중, 골연령, 흉위 순으로 나타났다.

흥미로운 것은, 앞서 언급한 상관분석에서 다양한 체격 항목이 체력항목과 밀접한 관련성이 나타난다는 것이다. 따라서 이 연구에 참여한 아동의 체격 변인과 수행력 변인 간 상관성이 높은 변인들, 특히 수행력의 예측력 $(\mathrm{r}=0.70$ 이상)이 높은 상하지 순발력을 대변하는 농구공 던지기, 제자리멀리뛰기 그리고 스피드를 대변하는 $50 \mathrm{~m}$ 달리기,

Table 6. Pearson's correlation of physical and physical factors in boys and girls

\begin{tabular}{|c|c|c|c|c|c|c|c|}
\hline & Type & $\begin{array}{l}\text { Age } \\
\text { (yrs) }\end{array}$ & $\begin{array}{l}\text { Bone Age } \\
\text { (yrs) }\end{array}$ & $\begin{array}{l}\text { Height } \\
(\mathrm{cm})\end{array}$ & $\begin{array}{l}\text { Weight } \\
(\mathrm{kg})\end{array}$ & $\begin{array}{c}\text { Chest } \\
\text { circumference } \\
(\mathrm{cm})\end{array}$ & $\%$ fat \\
\hline \multirow{3}{*}{$\begin{array}{l}\text { Basketball throw } \\
(\mathrm{cm})\end{array}$} & Total & $.542 * *$ & $.379 * *$ & $.705^{* *}$ & $.661 * *$ & $.548 * *$ & -0.059 \\
\hline & male & $.617^{* *}$ & $.459 * *$ & $.711^{* *}$ & $.652 * *$ & $.510 * *$ & 0.195 \\
\hline & female & $.647 * *$ & $.515^{* *}$ & $.780 * *$ & $.689 * *$ & $.524 * *$ & 0.112 \\
\hline \multirow{3}{*}{ Sit-up (rep) } & Total & $.370 * *$ & $.177^{*}$ & $.175^{*}$ & -0.001 & -0.085 & $-.268 * *$ \\
\hline & male & $.297 * *$ & 0.137 & 0.211 & 0.009 & -0.067 & $-.347 * *$ \\
\hline & female & $.456^{* *}$ & 0.205 & 0.162 & 0.013 & -0.074 & $-.379 * *$ \\
\hline \multirow{3}{*}{$\begin{array}{l}\text { Half squat jump } \\
\text { (rep) }\end{array}$} & Total & 0.083 & -0.098 & -0.124 & $-.273 * *$ & $-.278 * *$ & $-.497 * *$ \\
\hline & male & -0.02 & -0.094 & -0.154 & $-.354 * *$ & $-.343 * *$ & $-.571 * *$ \\
\hline & female & 0.263 & -0.071 & -0.104 & -0.201 & -0.261 & $-.426 * *$ \\
\hline \multirow{3}{*}{$\begin{array}{l}\text { Standing long } \\
\text { jump }(\mathrm{cm})\end{array}$} & Total & $.526^{* *}$ & $.290 * *$ & $.474 * *$ & $.248 * *$ & $.179 *$ & $-.431 * *$ \\
\hline & male & $.604 * *$ & $.374 * *$ & $.467 * *$ & 0.12 & -0.052 & $-.309 * *$ \\
\hline & female & $.710^{* *}$ & $.471^{* *}$ & $.551 * *$ & $.352 * *$ & $.312 *$ & -0.189 \\
\hline \multirow{3}{*}{$15 \mathrm{~m}$ pacer $(\mathrm{min})$} & Total & $.333 * *$ & 0.146 & 0.151 & -0.036 & -0.042 & $-.478 * *$ \\
\hline & male & $.369^{* *}$ & 0.176 & 0.187 & -0.044 & -0.115 & $-.437 * *$ \\
\hline & female & $.349 * *$ & 0.201 & 0.069 & -0.112 & -0.062 & $-.427 * *$ \\
\hline \multirow{3}{*}{$\begin{array}{l}50 \mathrm{~m} \text { running } \\
(\mathrm{sec})\end{array}$} & Total & $-.477 * *$ & $-.221 * *$ & $-.417 * *$ & $-.214^{*}$ & -0.132 & $.457 * *$ \\
\hline & male & $-.482 * *$ & $-.298 * *$ & $-.412 * *$ & -0.129 & 0.035 & $.350^{* *}$ \\
\hline & female & $-.685^{* *}$ & $-.334 *$ & $-.443^{* *}$ & -0.235 & -0.156 & $.286^{*}$ \\
\hline \multirow{3}{*}{ Side-step (rep) } & Total & $.548 * *$ & $.172 *$ & $.368 * *$ & 0.163 & 0.084 & $-.370 * *$ \\
\hline & male & $.663^{* *}$ & $.295 * *$ & $.447 * *$ & 0.082 & -0.149 & $-.285^{* *}$ \\
\hline & female & $.592 * *$ & 0.192 & $.280 *$ & 0.171 & 0.193 & -0.154 \\
\hline \multirow{3}{*}{$\begin{array}{l}\text { Trunk forward } \\
\text { flexion }(\mathrm{cm})\end{array}$} & Total & 0.021 & -0.082 & -0.087 & -0.143 & -0.132 & -0.048 \\
\hline & male & -0.028 & -0.188 & -0.174 & -0.183 & -0.161 & $-.248^{*}$ \\
\hline & female & 0.028 & -0.066 & 0.09 & 0.027 & 0.098 & $-.272 *$ \\
\hline \multirow{3}{*}{ Grip strength $(\mathrm{kg})$} & Total & $.624 * *$ & $.509 * *$ & $.642 * *$ & $.604 * *$ & $.491 * *$ & -0.034 \\
\hline & male & $.653 * *$ & $.571^{* *}$ & $.617 * *$ & $.575 * *$ & $.435 * *$ & 0.151 \\
\hline & female & $.717 * *$ & $.591 * *$ & $.704 * *$ & $.628 * *$ & $.499 * *$ & 0.061 \\
\hline
\end{tabular}

${ }^{*} p<.05,{ }^{* *} P<.01$ 
민첩성을 대변하는 사이드스텝과 근력을 대변하는 악력에 대한 회귀분석 모형을 〈Table 7〉에 제시하였다.

Table 7. Prediction model using multiple regression for physical performance by elementary school students' physique

\begin{tabular}{|c|c|c|c|}
\hline Variables & $\begin{array}{l}\text { Fitness } \\
\text { items }\end{array}$ & $\mathrm{r}^{*}$ & Prediction models \\
\hline \multirow{2}{*}{ Power } & $\begin{array}{l}\text { Basketball } \\
\text { throw }(\mathrm{cm})\end{array}$ & 0.764 & $\begin{aligned} 18.209 & \times \text { Age }-11.611 \times \mathrm{BA}+ \\
4.456 \times & \mathrm{H}+0.032 \times \mathrm{BW}+3.105 \\
& \times \mathrm{CC}-549.268\end{aligned}$ \\
\hline & $\begin{array}{l}\text { Standing } \\
\text { long jump } \\
\text { (cm) }\end{array}$ & 0.777 & $\begin{array}{c}8.683 \times \text { Age }-0.952 \times \mathrm{BA}+ \\
0.366 \times \mathrm{H}+0.761 \times \mathrm{BW}+0.348 \times \\
\mathrm{CC}-1.542 \times \% \text { fat }+7.275\end{array}$ \\
\hline Speed & $\begin{array}{l}50 \mathrm{~m} \\
\text { running } \\
(\mathrm{sec})\end{array}$ & 0.773 & $\begin{array}{c}14.440-0.382 \times \text { Age }+ \\
0.051 \times \mathrm{BA}-0.003 \times \mathrm{H}- \\
0.063 \times \mathrm{BW}+0.074 \times \times \% \text { fat }\end{array}$ \\
\hline Agility & $\begin{array}{l}\text { Side-step } \\
\text { (rep) }\end{array}$ & 0.726 & $\begin{array}{r}3.226 \times \text { Age }-0.768 \times \mathrm{BA}+ \\
0.115 \times \mathrm{H}-0.244 \times \% \text { fat }-2.2\end{array}$ \\
\hline $\begin{array}{l}\text { Muscle } \\
\text { strength }\end{array}$ & $\begin{array}{l}\text { Grip } \\
\text { strength } \\
(\mathrm{kg})\end{array}$ & 0.711 & $\begin{array}{c}1.587 \times \text { Age }-0.009 \times \mathrm{BA}+ \\
0.133 \times \mathrm{H}+-0.004 \times \mathrm{BW}+0.196 \\
\times \mathrm{CC}-31.915\end{array}$ \\
\hline
\end{tabular}

*: Pearson's correlation

$\mathrm{BA}=$ bone age, $\mathrm{H}=$ height, $\mathrm{BW}=$ body weight, $\mathrm{CC}=$ chest circumference.

\section{논 의}

본 연구에서는 체육영재 아동을 대상으로 운동수행력 과 관련이 있다고 제기된 유전자 중 Vitamin D receptor (VDR) Fok I 유전자 다형성을 분석하여 운동수행력에 영향을 미치는 체격, 체력요인과의 관련성을 살펴보고, 이 유전자의 특성이 아동기에 발현되는지 알아보기 위하 여, 유전자 분석을 실시하여 유전자 다형성별로 체격 및 체력 요인을 분석하였다.

\section{VDR 유전자 다형성 분포}

본 연구에서는 137 명의 $\mathrm{VDR}$ 유전자 다형성 분표가 $\mathrm{FF}$ 형 51명 (37.2\%), Ff형 76명 (55.5\%) 그리고 ff형 10 명 $(7.3 \%)$ 으로 나타났다. 본 연구의 VDR 유전자다형성 분포에 대한 Hardy-Weinberg 평형 결과에서 유의한 차 이가 나타났다 $\left(\chi^{2}=6.516, \mathrm{df}=2, \mathrm{p}=.038\right)$. 이러한 결과 는 본 연구에 참여한 대상자의 특성이 Hardy-Weinberg
평형을 이루지 않는다는 것을 의미하는 것이고, 이는 기 존의 VDR Fok I 의 분포와도 다르다는 것을 의미하는 것 이다. 즉, 본 연구에 참여한 체육영재 아동의 경우, 특정 유전자형이 분포가 높거나 낮다는 것을 의미하는 것으로 해석할 수 있다. 그 예로, 한국인 성인남녀 422 명을 대상 으로 한 연구(Park et al., 2017)의 VDR Fok I 유전자 다형성 분포를 살펴보면, $\mathrm{FF}$ 형 $33.9 \%, \mathrm{Ff}$ 형 $49.4 \%$ 그 리고 ff형 16.7\%으로 나타났다. Cheng \& Tsai (1999) 는 대만 여성을 대상으로 실시한 골밀도와 유전자 다형성 (Fok I)의 연구에서 $\mathrm{FF}$ 형, $\mathrm{Ff}$ 형 그리고 $\mathrm{ff}$ 형의 빈도는 각각 $35.6 \%, 49.5 \%$, 그리고 $14.9 \%$ 라고 보고하였다. 또 한 Song et al. (2006)의 유전자 조합분석을 통한 운동수 행력 예측 연구에서 꿈나무 $(\mathrm{n}=235)$ 선수는 $\mathrm{FF}$ 형 $33.9 \%, \mathrm{Ff}$ 형 $52.5 \%$, ff형 $11.4 \%$ 의 분포를 보였다고 보 고하였다. 이들 선행연구들에 비해 본 연구에 참여한 체 육영재 아동의 VDR Fok I 유전자형의 FF형은 비율 분 포가 높은 반면 ff형은 한국인을 대상으로 한 Park et al. (2017) 및 Song et al. (2006)의 연구에 비해 각각 약 9\% 유의하게 낮은 분포를 보였다. 이것은 체육영재프로 그램에 선발된 아동들의 경우, 낮은 분포비율의 ff형을 지 니고 있음을 의미하는 것이다.

한편, 일반인을 대상으로 한 연구들(Ames et al., 1999; Gross et al., 1996; Harris et al., 1997; Kanan et al., 2000)에서는 FF형이 ff형에 비해 높은 골 밀도(bone mineral density: $\mathrm{BMD}$ )를 지녔다고 보고한 바 있으며, 또한 이러한 $\mathrm{VDR}$ 의 유전자의 기능으로 인하 여 특정 유전자형에서의 근력과의 관련성이 제기된 바 있 다(Park et al., 2017; Song et al., 2006). 본 연구에서 는 실제 각 초등학교에서 우수한 체력을 지닌 학생들을 체육영재 선발 대상자로 추천 받았기에 어쩌면 VDR Fok $\mathrm{I}$ 유전자형 중에서 높은 $\mathrm{FF}$ 형의 비율 그리고 낮은 ff형 의 아동들이 참여했을 가능성을 배제할 수 없다.

\section{VDR 유전자 다형성에 따른 체격 및 체력요인 비교}

전체 대상자의 VDR 유전자 다형성별 체격 및 체력요인 을 $\mathrm{FF}$ 형과 $\mathrm{Ff}$ 형 및 $\mathrm{ff}$ 형으로 나누어 분석한 결과 집단 간의 체격 및 체력요인에 따른 유의한 차이가 나타나지 않았다. 이러한 결과는, 〈Table 3〉에서와 같이 좌전굴을 제외 
하고 여아보다 남아가 체력변인들에서 우수하였으나 남 아의 분포가 상대적으로 가장 낮은 $\mathrm{FF}$ 형 집단의 남아와 여아 모두 하프스쿼트 점프, $15 \mathrm{~m}$ 왕복달리기, $50 \mathrm{~m}$ 달리 기, 좌전굴에서 가장 높거나 빠른 경향을 보였다. 이것은 유전자형에 따른 남녀 아동의 분포와도 무관하지 않다. 즉, $\mathrm{Ff}$ 형과 유사한 남녀 아동 분포(남아 $60.5 \%$, 여아 $39.5 \%$ )를 $\mathrm{FF}$ 형 (남아 $54.9 \%$, 여아 $45.1 \%$ )에서도 보였 다면 아마도 유의한 차이가 나타났을 것으로 기대된다.

Nakamura et al. (2002)은 남자선수의 골의 표현형을 결정짓는 $\mathrm{VDR}$ 유전자 다형성의 잠재적 역할에 대해 연구 하였는데, 세 타입 중 ff형 $(\mathrm{n}=2)$ 의 빈도가 낮아 신체적 특 징의 차이가 나타나지 않아 ff집단을 제외하고, $\mathrm{FF}$ 와 $\mathrm{Ff}$ 형 두 집단만을 비교하였다. 또한 Ames et al. (1999)은 FF 형의 골밀도는 ff형보다 $8.2 \%$ 높았고, $\mathrm{Ff}$ 형에 비하여서는 $4.8 \%$ 높았다고 보고한 바 있기에, 본 연구에서는 FF형보 다 상대적으로 취약한 $\mathrm{Ff}$ 형과 $\mathrm{ff}$ 형을 하나의 집단으로 묶어 비교하였다. 그러나 마찬가지로 집단별 체격 및 체력 간의 유의한 차이는 나타나지 않았다. 이는 Song et al. (2006) 의 연구에서 일반인과 국가대표 선수 및 꿈나무선수의 체 격관련 변인에서 $\mathrm{VDR}$ 유전자 다형성 간에 유의한 차이는 없었다는 결과와 유사하였다. 이와 달리 성인을 대상으로 한 많은 연구에서는 $\mathrm{VDR}$ 유전자 다형성과 체격 및 체력요 인간의 유의한 차이가 발견된 경우도 있었다. 그 예로, 국 내 우수 성인 스피드 스케이트 선수를 대상으로 한 Kim et al. (2013)의 연구에서는 체격 변인에서는 이전 선행 연구 들과 마찬가지로 유의한 차이가 없었지만 체력 변인 중 무 산소 평균 파워에서만 유의하게 차이가 나타났다. 위의 선 행연구들은 유전자다형성과 1 회성의 운동능력을 비교했을 뿐만 아니라 대상자 수가 상대적으로 적고 ff형이 상대적으 로 적게 나타난데서 비롯된 결과일 것으로 사료된다. 따라 서 추후 VDR 유전자 다형성별 체격 및 체력요인을 분석하 기 위하여 대규모의 대상자를 확보한 장기간의 운동을 통 한 차이를 밝혀내는 연구가 필요할 것으로 판단된다.

\section{3. 남녀 아동의 체격 및 체력 요인에 대한 상관성을 토대로 한 특정 체력에 대한 예측}

흥미로운 것은 체육영재로 선발된 아동의 체격 및 체 력요인에 대한 상관관계를 분석한 결과, 지구력이나 심폐
지구력과는 달리 상하지 순발력, 스피드, 민첩성과 악력 과 같은 항목에서 매우 높은 상관성이 나타났다. 상하지 순발력을 대변하는 농구공던지기와 제자리멀리뛰기의 경우, 체격요인와 밀접한 상관성이 나타났고, 특히 독립 변인으로써 나이와 골연령이 매우 중요한 변인으로 작용 하는 것을 알 수 있었다. 즉, 초등학생의 경우, 나이 (chronical age)가 체격뿐 아니라 체력을 대변하는 주요 독립변인이 될 수 있으며, 동연령의 경우는 골연령 (bone age)이 주요한 독립변인이 될 수 있다는 것을 알 수 있었 다. 이러한 결과는 Ko et al. (2016)의 연구에서 제안한 초등학생들의 체격 특성을 반영하는 주요 변인이 골연령 이며, 신체수행력을 대변하는 주요 변인이 역연령과 체지 방률이라는 결과를 지지한 것이며, Beunen et al. (1997)이 제안한 아동청소년의 경우, 역연령, 골연령, 신 장 및 체중 변인들이 대부분의 수행력 항목을 대변하는 주요 요인이 된다는 연구결과와 유사한 것이다.

\section{결론 및 제언}

결론적으로, 좌전굴을 제외하고 여아보다 남아가 체력 변인들에서 우수하였으나 Ff형과 ff형에 비해 남아의 분 포가 상대적으로 가장 낮은 $\mathrm{FF}$ 형 집단의 남아와 여아 모 두 하프스쿼트 점프, $15 \mathrm{~m}$ 왕복달리기, $50 \mathrm{~m}$ 달리기, 좌 전굴에서 가장 높거나 빠른 경향을 보였다.

아동의 VDR 유전자 다형성에 따른 체격 및 체력 요인 의 유의한 차이는 나타나지 않았으나 $\mathrm{H}-\mathrm{W}$ 평형 검사에 서 일반인에 비해 유의하게 높은 $\mathrm{FF}$ 형과 낮은 ff형을 지 닌 것으로 나타났다. 이는 본 연구에 참여한 체육영재 아 동의 경우, 일반인에 비해 $\mathrm{FF}$ 형은 높은 반면 ff형은 낮은 분포를 보인다는 것이고, 이로 인하여 VDR 유전자형에 따른 체력 변인의 비교에서 유의한 차이가 나타나지 않은 주요 원인이 될 수 있다. 더욱이, 집단의 특성상 체력적으 로 우수한 아동들을 대상으로 하였기에 유전자형에 따른 유의한 차이가 나타나지 않았을 가능성 또한 배재할 수 없다. 따라서 VDR Fok I 유전자는 아동의 체력을 예측하 는 잠재적 가능성을 배재하기는 어려우나 그 가능성을 명 확하게 밝히기 위해서는 일반 아동들을 대상으로 한 추가 적인 연구가 이루어져야 할 것으로 판단된다. 


\section{참고문헌}

Ames, S. K., Ellis, K. J., Gunn, S. K., Copeland, K. C., Abrams, S. A. (1999). Vitamin D receptor gene Fok I polymorphism predicts calcium absorption and bone mineral density in children. J Bone Miner Res. 14(5):740-6. doi: 10.1359/jbmr. 1999.14.5.740.

Beunen, G. P., Malina, R. M., Lefevre, J., Claessens, A. L., Renson, R., Kanden, E. B. (1997). Skeletal maturation, somatic growth and physical fitness in girls 6-16 years of age. Int J Sports Med. 18(6):413-9. doi: 10.1055/s-2007-972657.

Bouchard, C., Daw, E. W., Rice, T., Perusse, L., Gagnon, J., Province, M. A. (1998). Familial resemblance for VO2max in the sedentary state: The HERITAGE family study. Med and Sci in Sports and Exercise 30(2):252-258.

Bouchard, C., Rankinen, T., Chagnon, Y. C., Rice, T., Perusse, L., Gagnon, J. (2000). Genomic scan for maximal oxygen uptake and its response to training in the HERITAGE family study. $J$ Applied Physiology 88(2):551-559.

Bray, M. S., Hagberg, J. M., Perusse, L., Rankinen, T., Roth, S. M., Wolfarth, B. (2009). The human gene map for performance and health-related fitness phenotypes: The 2006-2007 update. Med and Sci in Sports and Exercise 41(1):35-73.

Cheng, W. C., Tsai, K. S. (1999). The vitamin D receptor start codon polymorphism(Fok I) and bone mineral density in premenopausal women in Taiwan. Osteoporos Int. 9(6):545-9.

De Moor, M. H,, Spector, T. D., Cherkas, L. F., Falchi, M., Hottenga, J.J., Boomsma, D. I. (2007). Genome-wide linkage scan for athlete status in 700 british female DZ twin pairs. Twin Research and Human Genetics 10(6):812-820.

Geusens, P., Vandevyver, C., Vanhoof, J., Cassiman, J. J., Boonen, S., Raus, J. (1997). Quadriceps and grip strength are related th vitamin D genotype in elderly nonobese women. J Bone Miner Res. 12(12):2082-8.

Gross, C., Eccleshall, T. R., Malloy, P. J., Villa, M. L., Marcus, R., Feldman, D. (1996). The presence of a polymorphism at the translation initiation site of the vitamin $\mathrm{D}$ receptor gene is associated with low bone mineral density in postmenopausal Mexican-American women. J Bone Miner Res. 11(12):1850-5. doi: 10.1002/jbmr.5650111204.

Grundberg, E., Brandstorm, H., Ribom, E. L., Ljunggren, O., Mallmin, H., Kindmark, A. (2004). Genetic variation in the human vitamin D receptor is associated with muscle strength, fat mass and body weight in Swedich women. Eur $J$ Endocrinol. 150(3):323-8.

Harris, S. S., Eccleshall, T. R., Gross, C., Dawson-Hughes, B., Feldman, D. (1997). The vitamin D receptor start codon polymorphism (Fok I) and bone mineral density in premenopausal American black and white women. J Bone Miner. 12(7):1043-8. doi: 10.1359/jbmr.1997.12.7.1043.

Haussler, M. R., Whitfield, G. K., Haussler, C. A., Hsieh, J. C., Thompson, P. D., Selznick, S. H. (1998). The nuclear vitamin $\mathrm{D}$ receptor: biological and molecular regulatory properties revealed. J Bone Miner Res. 13(3):325-49.

Jackson, A., Pollock, M. L. (1985). Practical assessment of body composition. Physician Sportsmed. 13:76-90.

Kanan, R. M., Varanasi, S. S., Francis, R. M., Parker, L., Datta, H. K. (2000). Vitamin D receptor gene start codon polymorphism (Fok I) and bone mineral density in healthy male subjects. Clin Endocrinol (Oxf) 53(1):93-8. doi: 10.1046/j.1365-2265.2000. 01059.x.

Katsumata, K., Nishizawa, K., Unno, A., Fujita, Y., Tokita, A. (2002). Association of gene polymorphisms and density in Japanese girls. J receptor: biological and molecular regulatory properties revealed. J. Bone Miner Metab. 20(3):164-9.

Kim, C. W., Kim, J. H., Lee, D. B., Yoon, S. J. (2013). A study on anerobic ability and body composition of VDR gene polymorphism in short tract speed skaters. Korean J Phy Edu. 52(3):453-462.

Kim, H. G., Lee, S. J., Lee, S. C. (2008). Effect of difference types of exercise in bone mineral density and VDR gene polymorphism. Korean J Phy Edu. 47(2):481-490.

Ko, J. S., Lee, S. H., Kim, S. J., Park, D. H. (2016). The effect of chronological age (birth month) and bone age on physique and physical performance of children involved in athletic gifted children selection program. Exercise Science 25(2):110-119.

Lee, A. R., Jang, M. J., Choi, G. D., Lim, B. B. (2004). Bone density and polymorphism of VDR genes in athletes and the public. Korean J Phy Edu. 43(5):289-299.

Lortie, G., Simoneau, J. A., Hamel, P., Boulay, M. R., Landry, F., Bouchard, C. (1984). Responses of maximal aerobic power and capacity to aerobic training. Int $J$ Sports Medicine 5(5):232-236

McPherron, A. C., Lawler, A. M., Lee, S. J. (1997). Regulation of skeletal muscle mass in mice by a new TGF-beta superfamily member. Nature 387:83-90. 
Morrison, N. A., Qi, J. C., Tokita, A. (1994). Prediction of bone density from vitamin D receptor alleles. Nature 367:284-287.

Nakamura, O., Ishii, T., Ando, Y., Amagai, H., Oto, M., Imafuji, T., Tokuyama, K. (2002). Potential role of vitamin D receptor gene polymorphism $\mathrm{m}$ determining bone phenotype in young male athletes. J Appl Physiol. 93(6):1973-1979.

Park, D. H., Kang, J. H., Kim, C. S., Park, J. J., Song, W., Jung, D. S. (2009). Master plan for analysis and utilization of DNA to develop discriminant tools for athletic gifted children. Seoul: Korea Foundation for the Next Generation Sports Talent research report.

Park, D. H., Kim, C. S., Shin, Y. A. (2017). Association between the VDR FokI Polymorphism, Muscle Strength and Bone Strength in Male and Female Adults. Exercise Science 26(3):197-203.

Park, J. G., Shin, Y. O., Oh, J. G. (2005). The relationship between Vitamin D receptor \& estrogen receptor gene polymorphism and bone mineral density in athletes by types of exercise. Korean J Phy Edu. 44(5):421-429.

Rankinen, T., Perusse, L., m Rauramaa, R. Rivera, M. A., Wolfarth, B., Bouchard, C. (2004). The human gene map for performance and health-related fitness phenotypes: 2003 update. Med and Sci in Sports and Exercise 41(1): 35-73.

Rankinen, T., Perusse, L., m Rauramaa, R., Rivera, M. A., Wolfarth, B., Bouchard, C. (2002). The human gene map for performance and health-related fitness phenotypes: 2001 update. Med and Sci in Sports and Exercise 34(8):1219-33
Rankinen, T., Perusse, L., Rauramaa, R., Rivera, M. A., Wolfarth, B., Bouchard, C. (2001). The human gene map for performance and health-related fitness phenotypes. Med and Sci in Sports and Exercise 41(1):35-73.

Song, H. S., Park, D. H., Kim, C. S., Ko, B. G. (2006). Prediction of motor performance through combination analysis of endurance and muscle related genes. Seoul: Korea Institute of Sport Science Research Report

Tajima, O., Ashizawa, N., Ishii, T., Amagai, H., Mashimo, T., Liu, L. J. (2000). Interaction of the effects between citamin D receptor polymorphism and exercise training on bone metabolism. J Appl Physiol. 88:1271-71.

Tanner, J. M., Cameron, N., Healy, M., Goldenstatin, H. (2001). Assessment of skeletal maturity and prediction of adult height (TW3 Method) London, UK: W.B Saunders.

Thomis, M. A., Beunen, G. P., Van Leemputte, M., Maes, H. H., Blimkie, C. J., Claessens, A. L., Marchal, G., Willems, E., Vlietinck, R. F. (1998). Inheritance of static and dynamic arm strength and some of its determinants. Acta Physiol Scand. 163(1):59-71.

Wolfarth, B., Bray, M. S., Hagberg, J. M., Perusse, L., Rauramaa, R., Rivera, M. A., Roth, S. M., Rankinen, T., Bouchard, C. (2005). The human gene map for performance and health-ralated fitness phenotypes: the 2004 update. Med and Sci in Sports and Exercise 37(6):881-903. 


\title{
체육영재 아동의 VDR Fok I 유전자 다형성에 따른 체격 및 체력 비교
}

\author{
김유림 ${ }^{1}$, 이상현 ${ }^{2}$, 김수진 $^{2}$, 송정란 $^{3}$, 곽효범 ${ }^{4}$, 강주희 ${ }^{5}$, 박동호 $^{4}$ \\ ${ }^{1}$ 인하대학교, 석사 \\ ${ }^{2}$ 인하대학교 박사과정 \\ ${ }^{3}$ 인하대학교 시간강사 \\ ${ }^{4}$ 인하대학교 스포츠과학과 교수 \\ ${ }^{5}$ 인하대학교 의예과 교수
}

〔목적〕 본 연구의 목적은 체육영재아동의 비타민D 수용체(VDR) FokI 유전자 다형성에 따라 운동 수행력 에 영향을 미치는 체격과 체력의 차이를 분석하는 데 있었다. 〔방법〕 남아 82 명 $(9.1 \pm 0.9$ 세)과 여아 55명 (9.3 \pm 0.9 세) 137 명이 본 연구에 참여하였고, 이들의 FokI VDR 다형성이 분석되었다. 기본 체력변인(농구 공 던지기, 하프 스쿼트 점프, 제자리 멀리 뛰기, $15 \mathrm{~m}$ 옹복달리기, $50 \mathrm{~m}$ 달리기, 악력, 사이드 스텝, 체전굴, 윗몸 일으키기)과 체격 변인들은 One-way ANOVA 분석 후 유의한 차이가 있을 경우 사후분석으로 bonferroni test를 이용하여 분석하였다. (결과〕 남녀 아동 모두 VDR FokI 유전자형에 따른 체력 및 체격 변인 사이의 연관성은 발견되지 않았다. 하지만 Hardy-Weinberg 평형 결과에서 유의한 차이가 나타났다(x $2=6.516, \mathrm{df}=2, \mathrm{p}=.038$ ). (결론) 비록 VDR FokI 유전자다형성에 따른 체력변인에서의 유의한 차이는 나타나지 않았지만 $\mathrm{H}-\mathrm{W}$ 평형검사에서 유의한 차이가 나타났다. 이러한 점에서 VDR FokI 유전자가 체력을 예측할 수 있는 가능성을 배제하기는 어렵다고 판단된다. 따라서 체력을 예측할 수 있는 VDR FokI 유전자의 가능성을 확인하기 위해서는 일반 아동을 대상으로 한 추가적인 연구가 진행되어야 할 것이다.

주요어: VDR Fok1 유전자다형성, 아동, 체육영재, 체력, 체격 